Meta

Journal des traducteurs

Translators' Journal

\title{
The Plurality of Languages and Literature in Translation: The Post-Colonial Context
}

\section{Indra Nath Choudhuri}

Volume 42, numéro 2, juin 1997

Lexicologie et terminologie II (1) et Traduction et post-colonialisme en Inde

Translation and Postcolonialism: India (2)

URI : https://id.erudit.org/iderudit/002236ar

DOI : https://doi.org/10.7202/002236ar

Aller au sommaire du numéro

Éditeur(s)

Les Presses de l'Université de Montréal

ISSN

0026-0452 (imprimé)

1492-1421 (numérique)

Découvrir la revue

Citer cet article

Choudhuri, I. N. (1997). The Plurality of Languages and Literature in Translation: The Post-Colonial Context. Meta, 42(2), 439-443.

https://doi.org/10.7202/002236ar
Résumé de l'article

Le pluralisme linguistique en Inde n'est pas un signe defragmentation culturelle mais plutôt un atout, une reconnaissance des différences qui forment cette nation. La reconnaissance linguistique doit s'étendre au-delà des langues reconnues dans la Constitution indienne et englober celles qui occupent une position intermédiaire. Ainsi se trouve remise en cause la hiérarchie linguistique actuelle. 


\title{
THE PLURALITY OF LANGUAGES AND LITERATURE IN TRANSLATION: THE POST-COLONIAL CONTEXT
}

INDRA NATH CHOUDHURI

Sahitya Akademi, New Delhi, India

\begin{abstract}
Résumé
Le pluralisme linguistique en Inde n'est pas un signe de fragmentation culturelle mais plutôt un atout, une reconnaissance des différences qui forment cette nation. La reconnaissance linguistique doit s'étendre au-delà des langues reconnues dans la Constitution indienne et englober celles qui occupent une position intermédiaire. Ainsi se trouve remise en cause la hiérarchie linguistique actuelle.
\end{abstract}

\begin{abstract}
Linguistic pluralism in India is not a sign of social and cultural fragmentation but rather a positive force, a recognition of the differences which constitute the nation. This recognition needs to be extended beyond the languages recognized in the Indian Constitution to those which create an intermediary space, thereby subverting received hierarchies.
\end{abstract}

I need not emphasize that multilingualism is an all-pervading element in the Indian atmosphere, affecting every aspect of the country's life. Whereas developed countries are perceived as monolingual states due to their tendency to become dominantly monolingual as a result of their acceptance of a model of developmental culture which is effective only in a situation of monolingualism, the multilingualism of the entire third world is envisaged as problematic, particularly when developmental culture is viewed from the perspective of the developed world. From the western point of view a multiplicity of languages, religions and races is regarded as leading to fragmentation, even though, in fact, such rnultiplicity gives importance to every part of the whole. ${ }^{1}$ Rather, it is monolithic structures that may create fragmentation - of life, of man, and of knowledge -, undermining the unity of living. Any attempt to discuss the growth of Indian literature in terms of Sanskritization or Westernization smacks of cultural blinding. One simply cannot ignore the impact of the Bhasas (wrongly defined as regional languages) on each other, for they have been important in the historical perspective. The Atharva Veda, a very ancient book, explains that even in the ancient past there were many languages, many religions and many people staying in India together.

The affirmation of the positive value of cultural pluralism is the cornerstone of India's thinking and the model of developmental culture it has adopted. Thus, pandit Nehru was very keen to redraw the political map of India on the basis of linguistic states, replying critically to those who thought that linguistic states would make inter-linguistic and interregional movements impossible and that political boundaries would virtually seal off linguistic and cultural boundaries between the various regions of the country. The far-reaching effect was the emergence of the new regional, mass-based leadership, who pressed for the use of the Bhasas of different regions.

Nehru dismissed those who thought that it is a sign of disunity for a country to have too many languages. He termed the thought that India was a babble of languages, with its

Meta, XLII, 2, 1997 
hundreds and hundreds of languages, the cry of the ignorant. He said that India, as everyone who looks around can see, has singularly few languages considering its vast size and that these are intimately allied to each other. In his Autobiography he writes": "[...] if the Census tells us that India has two or three hundred languages it also tells us, I believe, that Germany has about fifty or sixty languages. I do not remember anyone pointing out this fact in proof of the disunity or disparity of Germany."

Nehru was extremely sure of his assertion that languages by themselves are not a destructive factor. In fact, Nehru always encouraged a multilingual situation as an expression of Indian culture. He was of the firm opinion that the growth of Bhasas did not tend at all towards disunity. ${ }^{3}$ But to predict that as the Bhasas gain in power, the Centre-State conflict will become more intense only indicates a wrong notion of the multilingualism of India. The unity of literary expressions despite their linguistic varieties, like Kalidasa's famous play Shakuntala, written in Sanskrit, Saurasheni, Maharastri and Magadhi, indicates that a literary text could be produced in a complex mulitlingual situation where different languages did not divide people into exclusive groups but could encourage people to interact with one another and to transcend linguistic barriers. ${ }^{4}$ Nehru felt that the renaissance of our Bhasas would help towards unification and would never be a destructive factor in India.

But the big question is that the language policy of the country, as exemplified by the eighth schedule, does not take cognizance of all the 1652 spoken languages, thereby empowering certain languages and marginalizing others, in the process unleashing disruptive and divisive forces and turning language from a socio-cultural reservoir and a communicative force into a political issue. ${ }^{5}$ Similarly the three-language formula ignores the minority languages. In every State 30 to 40 percent of the population speak minority languages, which can be divided into three categories: 1) tribal dialects, 2) minor languages, like Bundelkhandi, Bojpuri, Maghai, etc., within the States, 3) major languages of India which happen to be minority languages in a particular State, like Marathi or Tamil in Karnataka, or Urdu in Uttar Pradesh.

The State governments are generally reluctant to give instruction through the multiplicity of media of instruction to meet the needs of various linguistic groups among the students. It is often feared that recognizing the existence of dialects and of many small languages may lead to disintegration. Experience shows, however, that it is not the recognition, but the non-recognition of languages that has led to divisive movements. ${ }^{6}$ In a multilingual community like ours the age-old tradition which must be emphasized is that of linkage. The diverse languages and varieties of languages can be linked in various ways and one of the most effective of these is translation.

Translation is accepted as one of the ways of reconciling the interests of various groups. In fact, the programme of action of the new education policy of 1986 has, for the first time, included translation in its programme. It emphasizes that a serious effort at translating books from one language into another needs to be made, and the 1992 Perspective Paper on Education also reiterates this. It is true that in the name of multilingualism and equality we cannot develop a system where all the 1652 mothertongues are recognized and supported by the State and used for all functions. But, at the same time, this should not lead us to favour English and theorize that a choice of Bhasas is highly devisive politically. This kind of attitude goes against the character of multilingualism in India. The present difficulties in India cannot be reduced by replacing a language of power like English by another language of power and developing just one national language, but rather through encouraging an elaborate pattern of inter-regional, inter-ethnic communication. In fact, the natural development of bilingualism in FM radio programmes and Zee television news is a step towards evolving a strategy for the promotion of a language of wide circulation (LWC) and providing opportunities to subvert hierarchies and contest all forms of 
domination in a multilingual society, to create mutual interdependence and intersignification between languages. This kind of bilingualism can serve a double purpose. It can be an arena for confrontation, for resistance to the Other, ${ }^{7}$ and by Other I mean the language of the ex-colonizer. It can also be a means of self-liberation, through the continuous reworking and rewriting of two languages together, creating a bilingual text. In a multilingual society, the total range of modern sensibility, the whole cultural milieu and the total range of human experience can be expressed neither through English alone nor through any single Indian language, but by all languages of the people. The use of English as a 'metanarrative,' the idea that only English is a solution for the complex language problems, is false. The time has now come to 'reconstruct' the metanarrative and justify the other narratives for political and social justice. Already greater mobility among castes and subcastes in different parts of the country has made the enlarging of the Bhasa of that area a reality, displacing English-language elites by Bhasa elites, who represent for the most part the caste aspirations of non-Brahmins, and also displacing the hegemonic role of English, which is a barrier to civilizational creativity for the vast majority of Indians.

It is generally said that India is a translation area. We go on using two or three languages at a time. In our multilingual situation it is very natural for us to know more than one Indian language; thus, while speaking in the link languages - English and Hindi -, we are constantly using a translated language. Moreover, if we want to establish the concept of Indian literature as one literature, this will be possible only through translation. This is necessary for understanding both the basic unity and the wonderful diversities of Indian literature. In the Indian situation translation is ineluctable.

Despite the growing awareness of the importance of translation, there is no welldefined policy of translation, as Dr. Shantha Ramakrishna notes in her presentation of the National Seminar on Translation and Multilingualism in Post-Colonial Contexts. ${ }^{8}$ One nay question whether the absence of such a policy is creating rifts between languages, giving rise to artificially-created 'major' and 'minor' languages. We have already noted that the government policy of scheduling languages and the three-language formula have created divisions and muted the multilingual speakers in the country. The politics of link languages has allowed English to gain in strength more than Hindi as a job-selection language and as the language of power and control. Other languages, including the second link language, Hindi, are institutionally constrained and negatively treated in the public domains. All of this has created a crisis relating to the preservation of multilinguality in this post-colonial era, because colonialism still survives in a new avatara, in an altered form. ${ }^{9}$

It is necessary to point out that while nation-states, national ideologies, or government policies may require the use of a single, common language, such as English or Hindi, for administrative and political reasons, the centralizing language can neither be representative of a multilingual ethos and mosaic of cultures and ethnicities, nor expressive of peoples' creativity and vitality. It is, therefore, necessary to evolve more variegated but internally-connected forms of unity based on mutual bilinguality and exchange among languages commensurate with cultural complexity and diverse world views.

This cannot be achieved by simply cultivating bilinguality of the central language with other Indian languages, but rather by developing a mutually-enriching relationship among all the languages. After all, linguistic diversity in multilingual developing nations is not only inherently valuable but also creatively functional in relation to the civilizational and cultural complexity characteristic of the multilingual ethos. ${ }^{10}$

One could accuse the Sahitya Akademi (the National Academy of Letters) of perpetuating the hegemony of English or Hindi by using them as filter languages for translation from one Indian language to another. In defence of the Akademi, I should like to point out that because of the displacement of language from the centre of education and the use 
of the three-language formula more as a goal and not just as a strategy, which, in fact, is what should be the case, language competency has miserably declined, to such a degree that the new education policy shows concern for the question. As a result the language learning which was natural before 1947 has now been restricted to two or three languages, thereby creating a gap in translating directly in a multilingual setting. Hence agencies like the Sahitya Akademi are forced to use English or Hindi as filter languages for translation in its 22-language programme. This policy has surrepticiously created a division among languages. This is the tragedy of the post-colonial period because of our faulty language policy; it will therefore be proper not to devise in haste a policy of translation which would bring division among languages. What is necessary for a society does get translated, and this is not an innocent act. Social and cultural forces act to bring about translation. In 1994 the Sahitya Akademi extended its activities beyond the conventionallyset parameter of 22 recognized languages under its Language Development Programme. This extension ipso facto took the Akademi to the hills of the North-East to start interlingual translation in tribal languages including Chakma, Kok-Borok, Mong, Bodo, Khasi, Garo, Mising, Rabha or Reang, to fulfill the tradition of multiculturalism and multilingualism.

The major difference between translation practices in the West and translation practices in India is that in the West translation is considered a complicated linguistic and literary act, while in India it is an inevitable way of life. In the West translation has been subjected to scrutiny from a variety of perspectives, such as structuralism (Roman Jakobson), deconstruction (Jacques Derrida), psychoanalysis (Andrew Benjamin), gender (Lori Chamberlain), and post-colonial discourse (Lawrence Venuti). In India, in contrast, the focus has been more on the pragmatic aspects of translation. In the colonial context, translations of the colonizers' works attempted to "enrich" our languages, and translations of the classical Indian works into English were informed by a certain exoticism. These kinds of translation activities display the imbalance of power. Even in the post-colonial period, inequality is the main feature of the relationship between Western and ThirdWorld languages and cultures. In the colonial moment even a great writer like Tagore, while translating his poetry into English, appears to have accepted the hegemonic language and culture of Edwardian English and corrupted his own translation. Tagore seems to be tied to an ideology associated with colonialism and cultural domination, which has proved to be devastating for his works in translation. ${ }^{11}$

In the post-colonial moment the resistance of the dominated language-culture to neo-colonial hegemony is, at times, quite strong. Now one questions the validity of simply importing western intellectual production; the emphasis is on appropriating it in such a way to naturalize it within the dominated language-culture, within the framework of an "occidentalism." 12 Now the interest of Indian translators is to explore the ways in which the English language can be stretched to contain "authentic Indian expressions." At the same time, there is an attempt to view the English language as one of the Indian languages. It is for this reason that many Indians writing in English have also taken to translating from Indian languages. ${ }^{13}$ The growing weight of the intellectual production of cultural minorities has precipitated the emergence of a critique of the "universality" of Western translation theory. Now plurilingual writers, writing in the language of the ex-colonizer or in Bhasas are challenging and redefining many accepted notions in translation theory. We can no longer merely concern ourselves with the conventional notion of linguistic equivalence or ideas of loss and gain, which have long been a consideration in translation theory. The reason is the extensive use of different upbhasas (wrongly called dialects) by Indian novelists like Kambar, Debesh Roy, Krishna Sobti, and others, or the creation of a new language by Dalit writers or the use of tribal languages in multilingual contexts. These 
are the languages of the "in-between," which occupy a space "in between" and challenge conventional notions of translation, seeking to decolonize themselves from two oppressors: the Western ex-colonizer who naively boasts of their existence, and also the traditional "national" cultures, which short-sightedly deny their importance. Because of the "in between" it is possible now to create new models of translation theory. They are, in fact, subverting hierarchies by bringing together the dominant and the underdeveloped, by exploding and confounding different symbolic worlds and separate systems of signification in order to create a mutual interdependence and intersignification and not considering a translated text simply as an interface of culture-politics between the source languages and the target language. In view of the Indian tradition of multiculturalism and multilingualism translation becomes a very important instrument for us for negotiating social tensions, language conflicts, social transitions, and for identifying a plurality of linguistic expressions and cultural experience, and also for understanding the remarkable unity underlying them.

\section{Notes}

1. I. N. Choudhuri, "Dilemma of the Multilingual Society and the Culture of Development: The Indian Scene," Culture and Development: The Indian Situation, Working document for the National Seminar (1995), p. 104.

2. Jawaharlal Nehru Autobiography, New Delhi, Oxford University Press, 1985, p. 456.

3. Dorothy Norman, Nehru, Bombay, Asia Publishing House, 1965, p. 189.

4. Sisir Kumar Das, A History of Indian Literature 1800-1910. Western Impact: Indian Response, New Delhi, Sahitya Akademi, 1991, p. 5.

5. R. S. Gupta and Anvita Abbi, "The Eighth Schedule: A Critical Introduction," in Language and the State, R.S. Gupta, Anvita Abbi, and Kailash S. Aggarwal (Eds), New Delhi, Creative Books, 1995, p. 5.

6. I. N. Choudhuri, Comparative Indian Literature: Some Perspectives, New Delhi, Sterling, 1992, p. 216.

7. See Samia Mehrez, "Translation and the Post Colonial Experience," Rethinking Translation, Lawrence Venuti (Ed.), London, Routledge, 1992, pp. 120-137.

8. National Seminar Brochure, Jawaharlal Nehru University, on Translation and Multilingualism in PostColonial Contexts: Indian and Canadian Experiences, New Delhi, January 1996.

9. Makarand Paranjape, Decolonization and Development: Hindi Svaraj Revisioned, New Delhi, Sage Publications, 1993, p. 35.

1.0. Hans R. Dua, Hegemony of English, Mysore, Yashoda Publications, 1994, p. 253.

11. Mahasweta Sengupta, "Translation, Colonialism and Poetics: Rabindranath Tagore in Two Worlds," Translation, History and Culture, André Lefevere and Susan Bassnett (Eds), London, Pinter Publishers, 1990.

12. See Richard Jacquemond, "Translation and Cultural Hegemony: The Case of French-Arabic Translation," Rethinking Translation, Lawrence Venuti (Ed.), 1992, pp. 139-156.

13. G. N. Devy, "Language, Culture, Translation," presented at the Workshop on Language, Culture and Translation at the International India Centre from 31 October to 1 November 1992. 